\title{
Book Review: The Politics of Operations: Excavating Con- temporary Capitalism by Sandro Mezzadra and Brett Neilson
}

\author{
Juan Pablo Melo \\ Stanford University, Stanford USA, jmelo2@stanford.edu,www.juanpablom- \\ elo.com
}

Abstract: Juan Pablo Melo reviews Sandro Mezzadra and Brett Neilson's (2019) The Politics of Operations: Excavating Contemporary Capitalism. Durham, NC: Duke University Press.

Keywords: operations, media theory, Karl Marx, Antonio Negri, Italian Autonomism

\section{Introduction}

Marx's concept of the general intellect, discussed briefly though lucidly in the Grundrisse (1973), appears to refer to the collective human knowledge and praxis inscribed and literally objectified in a variety of manufactured artefacts, symbols, and even personality structures. The general intellect is materialized in the urban, suburban, and agricultural landscapes that define a given organization of territory, in the forms and operations inscribed in tools, techniques, and media, and even in the ideas, knowhow, habits, and symbols through which people perceive, communicate and act in the world.

The subsuming of the pragmatic management of metabolic relations under the general intellect therefore constitutes an epochal threshold, amounting to nothing less than the consolidation of capitalism as mode of production. According to Marx, this moment constitutes a qualitative inversion: from the subordination of technique to human interests, even if articulated within theocratic or mythical frameworks, to the subordination of human interests to functional imperatives. Marx develops here nothing less than a vision of the command of the dead over the living. Yet, the apocalyptic and science fictional dimensions conjured by Marx's notion of the general intellect are worth taking seriously, particularly in a context in which the global neoliberal apparatus seems intent on filtering catastrophic climate breakdown through the screen of profit and GDP-expansion models.

\section{The Operational Dimensions of Globalized Capitalism}

It is in this context that one can approach a recent work of major intentions if ultimately preliminary attainments: Sandro Mezzadra and Brett Neilson's (2019) The Politics of Operations: Excavating Contemporary Capitalism. In this text, Mezzadra and Neilson set out to do nothing less than come to terms with the history and present state of the general intellect as it relates to the consolidation and current expansion of capitalism - that is, with the functional integration of infrastructures, techniques, communications and information media, institutions, and knowledge under capitalist logics and with their role in remaking subjects and territories in line with these logics. Attuned to the "rhetoric of big data and algorithms that has gripped capitalist discourses and practices over the past half-decade" (2), the authors seek to 
bring these discourses back to earth, linking algorithmic chains and data mining to tangible processes of extracting value from collective practices, racialized and gendered bodies, and earthly minerals.

Motivating this investigation, then, is the imperative to trace three interrelated elements: the operational components of capitalism as determined by its constitutive political antagonisms; the "diversifying and homogenizing aspects" (3) of these operations, or the way they identify, incorporate, and equalize difference in line with the imperatives of capitalism; and the real material, subjective, territorial, and political arrangements and contestations that emerge out of capitalism's expansions and upheavals. At the heart of this study, then, is an attempt to think capitalism in all its political and material specificity at a time when its imbrication with media and communication technologies seems to render its operations and real material effects on territories and subjects ever more abstract, fluid, and disaggregated.

Given the enormity of the task it sets for itself, it is little surprise that this text seems to stage the concretion of critical theory into a general intellect. Encyclopaedic in its theoretical apercus, the book at times reads like a lengthy literature review intent on synthesizing the entirety of the critical academic catalogue, from the canonical repertoire - Althusser, Arendt, Gramsci, Harvey, Lefebvre, Lukacs, Luxembourg, Weber, etc. - to more recent contributions by media and postcolonial theorists such as Jussi Parikka and Verónica Gago. Closer inspection, however, reveals a wellcrafted organization of the argument that proceeds from the general to the concrete, and back again. The lengthy introduction frames extraction, logistics, and finance and their media-technological vehicles as operational enactments of the crisis-prone expansionary tendencies of capitalism that play out contingently in specific episodes of capital "hitting the ground". With this framing, Mezzadra and Neilson are able to manoeuvre beyond the scholastic differences that often block the linking of nodes here unified into a robust network of critical references. The critical theoretical arsenal, Mezzadra and Neilson show, can be brought together under a guiding impetus despite the finer points separating the genealogists of networks from the critics of ideology. An assemblage of concepts from sociology, critical geography, urban theory, feminist theory, anthropology, critical race theory, postcolonial theory, and media theory, is carried out here via the red thread of the primary operations that, according to the authors, define the development of capitalism today. As Mezzadra and Neilson approach it, the concept operations refers not only to the general tendencies of capital, but also to operations in a more prosaic sense - media-technological, institutional, ideological - as they are mobilized by these tendencies. Crucially, it is this procedural approach to the analysis of capitalism which gives this text its clarity and force, allowing it to dust off and reanimate Marxist critique along its synchronic and diachronic axes.

The emphasis on operations at the heart of Mezzadra and Neilson's analysis derives from the proposition that capitalism's structural class antagonisms drive its spatio-temporal fluctuations. Like Marx, who never tired of emphasizing that capitalism is not a system characterized by transcendental institutions, laws, techniques, and calculating subjects, but a social relation, Mezzadra and Neilson emphasize that capital and labour represent two poles in a social field characterized by conflict. It is precisely capital's striving to ensure the legal, political, and cultural conditions for capitalist accumulation in the face of the obstinacy of living labour that determines its expansionary tendencies.

With this line of argumentation, the authors signal their intellectual debt to Italian Autonomism - Mezzadra is a professor of political theory at the University of Bologna 
- and particularly with Antonio Negri's (1991) reading of the Grundrisse. For Negri, the self-valorisation of labour, the self-potentiating of the collective proletariat as it asserts its right to fulfil its historically quantified needs, perpetually undermines the capitalist maximization of profit. Capital has little recourse but to expand into its heterogenous outsides even as it strives to homogenize its interior in line with its functional imperatives. Capital's inherent antagonisms therefore link it tendentially though not deterministically towards the formation of a world market, towards the imposition of an abstract and global space for its movements. The book's first chapter therefore works out these ideas by introducing Marx's concept of the world market as a conceptual coordinate for framing mutations of territory, rights, and subjectivities against the background of capitalism's expansionary drive. The second chapter, meanwhile, uses Marx's concept of "aggregate capital," understood as the assemblage mobilized to speed up circulation and neutralize the processes of labour self-valorisation that jeopardize capitalist accumulation, as a representational heuristic for thinking about the state's role during different stages of capitalist expansion.

The authors hence engage in this section with the canonical field of political theory and propose a rethinking of questions of territoriality and the state. .The authors note that in early $20^{\text {th }}$ century Marxist writings, most notably in those of Luxemburg, Lenin and Hilferding, there was a convergence in the understanding that the state's role in stabilising crises and transforming the organic composition of capital was a crucial step in the socialisation of production. Through Keynesianism and the figure of the plan, the state's role in directing investment bound it to representing the unity of social aggregate capital. When the representation of social aggregate capital by the state became a limit to capitalist accumulation, there was a need to reconfigure monetary and financial arrangements, geographies of production, and modes of governance. The authors highlight that the development of cybernetics in post-WWII operational and military research was a media-technological component crucial in facilitating this wholesale global rearrangement of aggregate capital.

In the third chapter of the text, meanwhile, the authors carry out a more in-depth examination of the emergence of modes of authority and territory at the interstices of imperialist and colonial modes of capital accumulation. Moving closer to the present, they argue for a perspective that apprehends the global institutional and operational framings of contemporary capitalism as generative of new assemblages of territories and rights. They point out that the current form of globalized capitalism has produced novel territories, such as extraction or free trade zones, that have displaced the state's role in representing aggregate capital and in managing the reproduction of labour power. The result of these developments has been that the Weberian state, in which territory, community, and legitimacy are supposed to coincide, is increasingly destabilized by what the sociologist Saskia Sassen (2006) refers to as new assemblages of territory, authority, and rights.

Having articulated a diachronic analysis of the interrelation of capitalism's expansionary tendencies and the formation of the state in the book's first three chapters, in the fourth the authors focus on the current moment of capitalism, arguing that its interrelated operational modes are increasingly involved in forging relations of power and dominance in subjective and social realms of difference. In this section of the text, the felicitous conceptual potency that comes from mixing Marxist and media theories, meanwhile, blossoms in the insight that capitalism must be apprehended procedurally and that the workings of media-technological networks express its general tendencies. 
Extraction, logistics, and finance, the most salient operations defining capitalism today according to the authors, make use of digital technologies to facilitate new modes of spatio-temporal incorporation via the determination of heterogeneous fields ripe for homogenization and equalization - digital networks become the media through which capitalism touches upon its outsides. Mezzadra and Neilson emphasise that the operations in question are not to be understood as autonomous sectors of the economy, but as intersecting elements providing different framings for the activities of capitalism. Extraction, for instance, which typically refers to the appropriation and exploitation of natural resources, a process closely associated with Marx's concept of primitive accumulation, is increasingly linked today to the use of data mining to incorporate new modes of human cooperation, subjectivity, and biology under valorisation schemes. Yet if data can identify potential fields of value in the social and psychic realms, speculative finance is crucial in managing the time-lag between the incorporation of these realms into extractive frameworks and their valorisation. Data, for instance, can now be used by real estate speculators to prognosticate neighbourhoods "ripe" for gentrification, directing financial investment to these often racially marginalized areas even before the first hipsters, bohemians, and artists move in. Logistics, meanwhile, a set of operational techniques closely tied to the capitalist imperative to reduce the turnover time of production, distribution, and consumption cycles, draws upon data to coordinate global supply chains and develop real-time technologies of labour monitoring and disciplining.

As is evident from the previous examples, one of the advantages of Mezzadra and Neilson's approach is their ability to link operations that take place in the abstract reams of data or finance to concrete processes of extraction of land, resources, labour, social cooperation, and subjectivity, avoiding the fetishization of finance or the digital as realms in which materiality is sucked up without remainder. Mezzadra and Neilson's crucial insight, however, is that the outsides of capitalism are not just spatial, in the sense of that which lies geographically beyond the boundaries of capital, or temporal, in the sense of the battle over the working day. Rather, the outsides of capitalism encompass difference - racial, gendered, cultural, social, spatial, and temporal -as a generative field from which comparative equivalences are produced. Taking up Delezue and Guattari's (1987) notion of axiomatic capital, Mezzadra and Neilson therefore emphasise that capitalism is structured by commonalities yet variegated across geographies.

Mezzadra and Neilson are therefore keen to engage deconstructionist, postcolonial, and feminist critiques, assuming their insights and framing them within a critique of capital. The authors discuss, for instance, Cedric Robinson's (2000) thesis that during the Middle Ages the culture of the west developed by categorizing difference as racial, in that sense giving form to the future development of capitalism as an imperial and colonial enterprise. Yet, they note, denominations and incorporations of difference are fluctuating and not always entirely continuous from one historical regime of subjugation to another. In the present, for instance, difference is encoded in data models that catalogue and analyse preferences, actions, and probabilities along racialized categories to differentiate value-yielding from risky subjects. This operational approximation to difference therefore allows race and gender to be understood as fluctuating criteria for domination and for grounding forms of resistance.

The fifth chapter of the book, then, seeks to articulate a theoretical framing for comprehending exploitation and alienation in the current conjecture, and for forging vistas and categories for struggle and resistance. The sixth chapter brings this virtuoso analysis to its summation: here the authors attempt to sketch out the current 
state of capitalist globalization in its operational, territorial, normative, and political dimensions. They conclude the work by outlining the possible formation of a counterpower beyond capitalist and bureaucratic state logics.

\section{Marxism and Media Theory: Or, What Makes Operations Abstract?}

It is little surprise that a procedural and non-economistic approach to Marxist theory would eventually link up with a procedurally oriented media theory. Neilson, a professor at the Institute for Culture and Society at Western Sydney University who has cooperated in producing an edited volume with Ned Rossiter (2017), supplies the media theoretical supplement that gives this work its bibliographical breadth. This supplement and the engagement with media theory that it potentiates, is evident, for instance, in the authors' discussion of the intensification of the split between abstract and living labour gestured at with the concept of algorithmic capitalism (Rossiter 2016). Here the authors argue that it is important, in this case, not to reduce algorithmic operations to technical procedures. For "the political and subjective element of labor is not captured through an exclusive emphasis on technical operations, even as they clearly intersect and establish the conditions for the production of subjectivity" (86).

This theoretical point of difference, which arises at the intersection of Marxist analysis with media theory, is worth reflecting on. The theoretical frameworks underlying media theory often focus on highlighting the imbrication and co-constitution of humans and their tools and the media-technological framing of meaning networks within which the human as construct emerges, to the detriment of analyses of capitalist dynamics, class antagonism, and ideology critique. At a fundamental level, there are no doubt deep discrepancies in the philosophical foundations of media theory and Marxism. Questions arise, for instance, when one tries to think through the normative claims of Marxist critique from a post-humanist media theoretical framework. What constitutes a non-alienated form of being and a radically democratic or post-capitalist collective? Where and how does the non-human enter into such formulations?

On the other hand, the points of intersection between the two theoretical models are increasingly evident - even if one ignores the legacy of Althusser's (2005) critique of humanism. New trends in media theory and post-humanist inquiry have progressively expanded their scope from the tracing of media-technological genealogies to general reflections on the positional, procedural, and operational elements of mediation in all its forms - analogue, digital, infrastructural, elemental. It is on this terrain, which takes to its furthest reaches the nominalist insights on the historicity and artificiality of human/non-human and nature/artificial epistemic boundaries and dualities, that Marxist and media-technological inquiries find common ground. Although not specified in the text, what The Politics of Operations gestures to is the need to produce a Marxist media theory, a materialist media theory that approaches capitalism as a network of media-technological and operational chains inscribed in infrastructures, institutions, technologies, ideologies, and even personality structures but a Marxist media theory that retains a space and perspective for a normatively oriented and framed ideology critique.

The strengths of Mezzadra and Neilson's theoretically eclectic approach are evident. This approach allows them to undertake sweeping analyses of the transformations of territory and its component elements as these took place operationally as a factor of the management of the reproduction of labour by aggregate capital. This expansive and somewhat dizzying tour-de-force makes clear that the fruitfulness of an operational analysis of capitalism, however, also runs into a representational 
problem: the large-scale, complex, and increasingly abstract and digitally mediated synchronic and diachronic developments of capital short-circuit any cognitive mapping of capital. Mezzadra and Neilson therefore emphasize the dual optics from which capital must be analysed. At its most general they approach capitalism from the perspective of the heterogeneity that composes it as a machine intent on identifying and homogenizing all difference. This perspective allows the authors to carry out a sweeping synchronic and diachronic overview of the general trends of capitalist development while emphasizing its contextual variability and contingency. In short, their methodology allows the authors to define shifting signifiers such as state, territory, citizen, law, race, and operations, against the general conceptual framework of the general tendencies of capital as analysed by Marx.

And yet, one gets the sense that their theoretical model is in need of further justification. Perhaps what is lacking here is a more deep-seated meditation on the philosophical presuppositions assumed with the concepts of materiality, mediation, operation, and abstraction - key concepts for Marxism and media theory.

That this may be the case is signalled by the fact that it is precisely in working through the juxtaposition of materiality and abstraction/mediation that Mezzadra and Neilson seem to come short. As the authors note, the problem of abstraction (and of the general intellect as conceived by Marx) is already present in Leibniz's emphasis on the possible detaching of operations from human agency. The authors also mention that for Alfred Sohn-Rethel (1978), capitalism was indeed characterised by its power of real abstraction, by the problem posed by abstractions such as the commodity, labour, or money as they constituted and increasingly shaped a whole set of social relations. Mezzadra and Neilson see real abstraction as operating along axes of circulation and equalization, of abstraction and materiality. But this proposition raises a set of questions. How does one distinguish between the material and the abstract at the level of an operation? Does one, for instance, take recourse in Marx's juxtapositions of use values vs. exchange values, or living labour vs. dead labour?

The closest the authors come to answering these questions is a short engagement with Hannah Arendt's (1998) notions of labour, work, and action. Responding to Arendt, Mezzadra and Neilson argue that an operation is connected with the fabrication of an artificial world but not necessarily with the production of a work or a thing. The term operation refers to the production of the connections, chains, and networks that materially frame the labour and action of subjects. For the authors, the operations of capital increasingly blur the boundaries of labour, work, and action, as Arendt understood them. Actions are now flung beyond the spatio-temporal perspectives of their agents, reworking the boundaries between human and nonhuman, and reconfiguring assemblages of territory and rights.

\section{Praxis for the Conjecture}

For all the fecundity of Mezzadra and Neilson's analysis of the operational dynamics of globalized capitalism, what seems to be missing from their diagnosis is a sharper articulation of the recursive interrelation of communication and media-technological networks. Despite the sophisticated integration of Marxist theory with media theory in evidence in the text, there is a need to link an operationally oriented critique of capitalism to an analysis that takes into consideration how media-technological networks and lifeworlds are mutually and materially constituted, how persons capable of action emerge at their interstices, and how abstraction is a matter of levels of mediation and operational reifications. 
These theoretical shortcomings do not hamper Mezzadra and Neilson's capacity to track the general trends of capitalist development. However, they do seem to narrow the range of proposed political strategies for approaching the current conjecture. Bound to the Spinozist/Autonomist concept of potenza and to the figure of the collective revolutionary subject, Mezzadra and Neilson call for a sovereign social power to resist capitalism via logics different than those that regiment the bureaucratic and representative state. Going beyond the similarities between this dual power and the liberal notion of civil society, the nature of abstraction in a digitally mediated world makes this proposition theoretically problematic. From a consistent materialist and proceduralist perspective, abstraction would refer to normative and media-technological mediations inextricable from the post-traditional differentiation of collectives, perspectives, interests, opinions, needs and personality structures. A Marxist analysis would have to accept complexity and mediation in the spatio-temporal, institutional, social, and subjective realms as fully consistent with a post-capitalist constellation. Engaging media theory means revealing the logocentric, face-to-face communicational Arendtian public sphere for the ideological illusion that it is. For, as Mezzadra and Neilson aptly show, it is evident that the institutions of the liberal democratic state failed to reign in the reified operations of capitalism and were ultimately overloaded by its operational tendencies - with grave consequences for the sustainability of life at the planetary scale.

In short, a socialist framework would have to determine new cooperative and democratic modes of organising labour, work, and action while respecting social complexity and the multiplicity of differences. Clearly, the setting up of reified networks of operations that proceed by equalizing difference in line with functional imperatives would be incompatible with such a post-capitalist framework. Other forms of abstraction, however, which refer to the operational chains that potentiate logistical and communicative capacities, will remain crucial to planning production and reproduction and to democratizing the institutions and forums of work, labour, and action. It is through as-yet non-existent radically democratic institutions, norms, and modes of relation, as they mobilize media-technological networks and their operational capacities, that we can ensure that cycles of production, distribution, and consumption, and of reproduction, technics, and action, as they integrate and interrelate the human and the non-human, are subordinated to normative rather than functional imperatives. The question seems to be: What level of abstraction are we willing to live with as we seek to mobilise media-technical and normative operations to reorganise the nexus of labour, work, and action, beyond capitalist and humanist frameworks?

As Mezzadra and Neilson show in their operational assessment of capitalism, answering this question runs through an analysis able to mix Marxist critique with the procedural insights of media theory, insights which highlight the material dimensions of mediation, positionality, and recursivity. The greatest achievement of the text is therefore its capacity to reframe capitalism as a social relation which structures media-technological operations in line with its constitutive political antagonisms and functional imperatives. The general intellect, therefore, is wholly material along all its axes, but the network of technical operations is always open to collective and intentional redirection and reconfiguration under different political arrangements, and for different ends.

\section{References}

Althusser, Louis. 2005. For Marx, translated by Ben Brewster. London: Verso.

Arendt, Hannah. 1998. The Human Condition. Chicago: University of Chicago Press. 
Deleuze, Gilles and Félix Guattari. 1987. A Thousand Plateaus: Capitalism and Schizophrenia, translated by Brian Massumi. London: Athlone.

Marx, Karl. 1973. Grundrisse. Introduction to the Critique of Political Economy. New York: Random House.

Mezzadra, Sandro and Brett Neilson. 2019. The Politics of Operations: Excavating Contemporary Capitalism. Durham: Duke University Press.

Negri, Antonio. 1991. Marx Beyond Marx. Lessons on the Grundrisse, translated by Harry Cleaver, Michael Ryan and Maurizio Viano, edited by Jim Fleming. New York: Autonomedia.

Neilson, Brett and Ned Rossiter. 2017. Logistical Worlds: Infrastructure, Software, Labour. No. 2, Kolkata. London: Low Latencies.

Robinson, Cedric. 2000. Black Marxism: The Making of the Black Radical Tradition. Chapel Hill: University of North Carolina Press.

Rossiter, Ned. 2016. Logistical Nightmares: Infrastructure, Software, Labour. London: Routledge.

Sassen, Saskia. 2006. Territory, Authority, Rights. Princeton, NJ: Princeton University Press. Sohn-Rethel, Alfred. 1978. Intellectual and Manual Labour: A Critique of Epistemology. London: Macmillan.

\section{About the Author}

\section{Juan Pablo Melo}

Juan Pablo Melo is a Ph.D. Candidate at the Program in Modern Thought and Literature at Stanford University. He holds an MA in English, and his research focuses on the intersections of aesthetic, technology and politics in the city. You can learn more about his work at www.juanpablomelo.com 